\title{
Contents Volume 2
}

\section{No. 1}

Risk and safety in radiography in women of childbearing ability R.H. Pearson (U.K.)

Ethics in the pharmaceutical industry: acceptance of responsibility or a facet of marketing?

P. Chirac (France)

Concomitant drug use among patients on cardiac glycosides H.G. Leufkens, R.M.C. Herings, W.J. Kollöffel and A. Bakker (The Netherlands)

Prevention of adverse reactions to intravascular contrast media P. Soyer, M. Levesque and P. Rouleau (France)

Drugs after 1992; an equation with many remaining unknowns E.J. Boer (The Netherlands)

Detecting adverse drug reactions - a concise update. I. Cohort and case control studies D.H. Lawson (U.K.)

Detecting adverse drug reactions - a concise update. II. Monitored release R.D. Mann (U.K.)

Detecting adverse drug reactions - a concise update. III. The record-linkage system: a duality of purpose

M.L. Morse (U.S.A.)

Reviews of books and studies

Forthcoming Meetings $\quad 59$

$\begin{array}{ll}\text { Announcement from the Publisher } & 60\end{array}$

$\begin{array}{ll}\text { Information for Authors } & 61\end{array}$

Nos. 2,3

Risk management: a practical approach

The physician's civil liability under Danish law $N$. Fenger and M. Broberg (Denmark) 
What is risk management?

G. Hill (U.K.)

Is risk management necessary?

R. Dingwall and P. Fenn (U.K.)

Risk management in trauma and orthopaedics

R. Vickers (U.K.)

Risk management in anaesthesia A.R. Aitkenhead (U.K.)

Risk management in surgery

J.C. Smith (U.K.)

The risks of obstetrics and gynaecology in practice

G. Chamberlain (U.K.)

Risk management in obstetrics and gynaecology C.E. James (U.K.)

Risk management implementation programmes

G. Roberts (U.K.)

\section{Regular Papers}

Extra-hospital dialysis: the patient is at risk, not the method B. Viron and F. Mignon (France)

Electrical safety in patient care areas R. Cislo and B. Rasaiah (Canada)

Meeting Report: Health foods or healthy foods 161

Reviews of books and studies 165

Information for Authors $\quad 169$

No. 4

Classifying improvements to drug marketing and justifications for claims of efficacy P.R. Mansfield (Australia)

Adverse drug reactions: scope and limitations of causality assessment and the use of algorithms

W. Castle (U.K.)

Editorial Note: Care and cholesterol G. Dukes 
The long-term safety of antihyperlipidaemic drugs

O.R. Ødegaard (Norway)

Monitoring the long-term safety of lipid lowering therapy

J.F. Walker (U.S.A.)

Problems and possibilities of spontaneous adverse reaction reporting systems K.H. Kimbel (Germany)

Registration of post-operative wound infections: a method for reducing the rate of infections

N. Darle, A. Falk, M. Hall-Angerås and H. Thunberg-Sjöström (Sweden)

Hippocrates

Reviews of books and studies

Forthcoming Meetings

Information for Authors

No. 5

The International Clearinghouse for Birth Defects Monitoring Systems

Editorial: Monitoring birth defects

The International Clearinghouse for Birth Defects Monitoring Systems: Past, present and future

J.D. Erickson (U.S.A.)

What does it mean to be a member of the Clearinghouse?

E. Robert and M.L. Martínez-Frías (France, Spain)

An ICBDMS collaborative study: monitoring multimalformed infants P. Mastroiacovo (Italy)

Birth defects monitoring in underdeveloped countries: an example from Uruguay

E.E. Castilla, J.S. Lopez-Camelo, G.P. Dutra and J.E. Paz (Brazil, Argentina)

Statistical methods for surveillance of congenital malformations: when do the data indicate a true shift in the risk that an infant is affected by some type of malformation?

R.T. Lie, S.E. Vollset, B. Botting and R. Skjwerven (Norway, U.K.) 
No. 6

$\begin{array}{ll}\text { Editorial } & 303\end{array}$

Fatal adverse drug reactions reported in Denmark 1968-1988

H. Kromann-Andersen, M. Andersen, H.O. Andersen and P. Juul (Denmark) 305

Risk evaluation and estrogens

I. Palmlund (U.S.A.) 321

Risk, estrogens - and a poem 343

An international survey on drug utilization during pregnancy. Collaborative Group on Drug Use in Pregnancy (CGDUP) 345

Law Notes 351

Hippocrates $\quad 355$

$\begin{array}{ll}\text { Reviews of books and studies } & 359\end{array}$

Contents Volume 2 363 